\title{
The Lifeboat Ethics And Humanist Ethics: Similarities And Dissimilarities
}

\author{
Paul Appiah-Sekyere \\ Department Of Religion And Human Values \\ University Of Cape Coast. Cape Coast, Ghana
}

\begin{abstract}
Albeit both the Lifeboat ethics and Humanist ethics have similar sources, namely, reason and science, there are dissimilarities in their respective ethical values that outnumber the similarities. This study examines how two ethics that have similar sources can produce similar and dissimilar ethical values to the extent that the latteroutnumber the former.
\end{abstract}

Key words: Ethics, Humanism, Lifeboat.

\section{INTRODUCTION}

Both the Humanist ethics and the Lifeboat ethics have common sources, namely, human reason and scientific method.Notwithstanding their common sources, they contain several moral values/principles that are dissimilar. This paper examines Humanist ethics and the Lifeboat ethics identifying the similarities and dissimilarities among them.

\section{Ethics}

Singer (1993) sees ethics as the philosophical study of morality. ${ }^{1}$ Thus, ethics is also known as moral philosophy. Singer sometimes uses ethics and morality interchangeably. For Boss (1997), ethics is a philosophical discipline that studies the values and guidelines by which we live,-as well as the justification of these values and guidelines. ${ }^{2}$ According to Gonsalves (1989), "ethics is both a practical and normative science that discovers, explains, and demonstrates the principles and rules of right conduct."3

\section{The Lifeboat Ethics}

Garrett Hardin (1974) propounded the lifeboat theory which is the substratum of the lifeboat ethics. In order to gain a profound appreciation of the lifeboat ethics, it is worthwhile to know the background of the mastermind of this ethics.

\section{Garrett Hardin's Background ${ }^{4}$}

Garrett Hardin was born in Dallas, Texas in the year 1915. His father was a freight sales representative with the Illinois Central Railroad. Although the family moved frequently because of his father's job, they had secure roots in his grandfather's farm in South-Western Missouri. Hardin's high school and college days were spent in Chicago. He showed promise in

\footnotetext{
${ }^{1}$ See Singer, P. (1993). A companion to ethics. Mass.: Blackwell.

2Boss, J. A. (1997). Perspectives on ethics. California: Mayfield Publishing Company.

${ }^{3}$ Gonsalves, M. A. (1989). Fagothey's Right \& reason: Ethics in theory and practice.New Jersey: Prentice Hall, p. 7.

${ }^{4}$ Hardin, G. (1974). Lifeboat ethics: The case against helping the poor, from http://www.garretthardinsociety.org/a rticles/art_lifeboat_ethics_case_against_helping_poor.html, Retrieved 04/04/2015.
} 
writing from an early age. At the age of fifteen (15) he won a city-wide contest run by the Chicago Daily News with an essay on the importance of Thomas Edison. For this, he was awarded a trip, East to visit the aging inventor.

In the year 1932, Hardin won both a University of Chicago academic scholarship and a dramatic arts scholarship at the Chicago College of Music. A month's attendance convinced him that he could not follow both paths simultaneously, and so he abandoned the dramatic scholarship. In the year 1936, Hardin graduated from the University of Chicago in zoology, studying under the ecologist W. C. Allee. Garrett Hardin then transferred to Stanford University, where he obtained his Ph.D. in microbial ecology in the year 1941. His most influential mentors were the microbiologist C. B. van Neil and the geneticist George W. Beadle, later to be awarded the Nobel Prize. Shortly after graduation, Hardin began to work at the Carnegie Institution of Washington's Division of Plant Biology, which had a laboratory on the Stanford campus. For four years, he was part of a team investigating antibiotics produced by algae, as well as the future possibility of using cultured algae as animal food.

In the year 1946, Hardin resigned his research position at the Carnegie Institution to accept an associate professorship at the University of California's campus in Santa Barbara. During the next two decades he devoted much of his time to developing an ecologically-oriented course in biology for the general citizen, which he adapted to closed-circuit television. He was appointed full professor of human ecology in the year 1963.

Hardin's work on population control and immigration reduction has been supported by grants from the Pioneer Fund from the year 1988 through 1992. He died on 14th September, 2003.

\section{The Lifeboat Theory ${ }^{5}$}

So here we sit, say fifty (50) people in our lifeboat. ${ }^{6}$ To be generous, let us assume it has room for ten (10) more, making a total capacity of sixty (60). Suppose the fifty (50) of us in the lifeboat see hundred (100) others swimming in the water outside, begging for admission to our boat or for handouts. We have several options: we may be tempted to try to live by the Christian ideal of being "our brother's keeper," or by the Marxist ideal of "to each according to his needs." Since the needs of all in the water are the same, and since they can all be seen as "our brothers," we could take them all into our boat, making a total of one hundred and fifty (150) in a boat designed for sixty (60). The boat swamps, everyone drowns. Complete justice, complete catastrophe.

Since the boat has an unused excess capacity of ten (10) more passengers, we could admit just ten (10) more into it. But which ten (10) do we let in? How do we choose? Do we pick the best ten (10), "first come, first served"? And what do we say to the ninety (90) we exclude? If we do let an extra ten (10) into our lifeboat, we will have lost our "safety factor," an engineering principle of critical importance. For example, if we do not leave room for excess capacity as a safety factor in our country's agriculture, a new plant disease or a bad change in the weather could have disastrous consequences. Suppose we decide to preserve our small safety factor and admit no more to the lifeboat. Our survival is then possible although we shall have to be constantly on guard against boarding parties. While this last solution clearly offers the only

\footnotetext{
${ }^{5}$ Hardin, G. (1974). Lifeboat ethics: The case against helping the poor, from http://www.garretthardinsociety.org/a rticles/art_lifeboat_ethics_case_against_helping_poor.html, Retrieved 04/04/2015.

${ }^{6}$ Garrett Hardin uses the term lifeboat in a metaphoric sense. Cf. Sydney D., Ta'Von J. and Arman Ali, "Analysis of 'Lifeboat Ethics”" from http://hardinlifeboatethics.weebly.com/formal-essay-analysis-of-lifeboat-ethics.html. Retrieved 29/05/2016.
} 
means of our survival, it is morally abhorrent to many people. Some say they feel guilty about their good luck. My reply is simple: "Get out and yield your place to others." 7 This may solve the problem of the guilt-ridden person's conscience, but it does not change the ethics of the lifeboat. The needy person to whom the guilt-ridden person yields his place will not himself feel guilty about his good luck. If he did, he would not climb aboard. The net result of conscience-stricken people giving up their unjustly held seats is the elimination of that sort of conscience from the lifeboat.

\section{Humanism}

Humanism has been defined severally. Each definition, however, captures the basic tenets of Humanism. According to the American Humanist Association, Humanism is a Philosophy and value system that seeks the total wellbeing of humans here and now without any belief in a personal deity or "higher power."8The International Humanist and Ethical Union (IHEU), defines Humanism as follows:

Humanism is a democratic and ethical life stance which affirms that human beings have the right and responsibility to give meaning and shape to their own lives. It stands for the building of a humane society through an ethics based on human and other natural values in a spirit of reason and free inquiry through human capabilities. It is not theistic, and it does not accept supernatural views of reality. ${ }^{9}$

According to the American Humanist Association (AHA), Humanism is a Philosophy and value system that seeks the total wellbeing of humans here and now without any belief in a personal deity or "higher power."10 Precisely, the American Humanist Association, "Humanism is a progressive life stance that, without supernaturalism, affirms our ability and responsibility to lead meaningful, ethical lives capable of adding to the greater good of humanity (http://www.americanhumanist.org).

Humanism does not accept any supernatural reality. For humanists, there is no heaven or hell, no netherworld. Humanism does not believe in the life hereafter and similar views that are espoused by some religions such as Christianity and Islam.

Defining Humanism, the Bristol Humanist Group maintains that "Humanism is an approach to life based on reason and our common humanity, recognizing that moral values are properly founded on human nature and experience alone" (http://www.nfuu.org/definitionsof humanism.htm). The definition of the Bristol Humanist Group accentuates reason and the common nature of humans. In fact, all the aforementioned definitions clearly affirm that Humanism does not accept supernaturalism. Humanism believes that humans are naturally capable of living meaningful lives without any reference to a supernatural being or deity. AHA affirms this stance by asserting that "Humanism is a progressive life stance that, without

${ }^{7}$ Hardin, G. (1974). Lifeboat ethics: The case against helping the poor, from http://www.garretthardinsociety.org/a rticles/art lifeboat ethics case against helping_poor.html.Retrieved 04/04/2015.

${ }^{8}$ American Humanist Association, Humanist manifestos $i$ \& ii, http://www.americanhumanist.org- Retrieved 03/03/2016. See also Humanist manifestos i \& ii, in Lamont, C. (1997). The philosophy of Humanism (8 ${ }^{\text {thEd.). }}$ Amherst, New York: Humanist Press, pp. 310-327.

${ }_{9}$ American Humanist Association, Humanist manifestos i \& ii, http://www.americanhumanist.org-Retrieved 03/03/2016; See also http://www.iheu.org/amsterdamdeclaration.Confer also Humanist manifestos i\& ii in Lamont, C. (1997). Op. Cit..

${ }^{10}$ American Humanist Association, Humanist manifestos $i$ \& ii, http://www.americanhumanist.org- Retrieved 03/03/2016. See also Humanist manifestos $i$ \& ii, in Lamont, C. (1997). The philosophy of Humanism (8 ${ }^{\text {thEd.). }}$ Amherst, New York: Humanist Press, pp. 310-327. 
supernaturalism, affirms our ability and responsibility to lead meaningful, ethical lives capable of adding to the greater good of humanity. ${ }^{11}$

Furthermore, Humanism is a democratic and ethical life stance that claims that human beings have the right and responsibility to give meaning and shape to their own lives. It stands for the building of a humane society through an ethics based on human and other natural values in a spirit of reason and free inquiry through human capabilities. It is not theistic, and it does not accept supernatural views of reality. ${ }^{12}$

For the Bristol Humanist Group, Humanism is an approach to life based on reason and our common humanity, recognizing that moral values are properly founded on human nature and experience alone. ${ }^{13}$

Corliss Lamont (1996) defines Humanism as a philosophy of joyous service for the greater goodof all humanity in this natural world and for advocating themethods of reason, science, and democracy. ${ }^{14}$

\section{Humanist Ethics}

Humanist ethics relies on reason and scientific method ${ }^{15}$ and does nothave faith in prayer, divine revelation or a supernatural God for the solutionof ethical or other problems.

Reason and intelligence are the most effective instruments that humankind possesses. There is no substitute: neither faith nor passion suffices in itself. The controlled use of scientific methods, which have transformed the natural and social sciences since the Renaissance, must be extended further in the solution of human problems. But reason must be tempered by humility, since no group has a monopoly of wisdom or virtue. ${ }^{16}$

Humanist ethics deals with the values of right, wrong, good, evil, and responsibility according to the beliefs/teachings of Humanism. Humanist ethical principles ${ }^{17}$ include the following:

- Morality stems from our situation as social beings.

- The emphasis is on the human being and the here-and-now.

- The origin of morality/ethics is the human society without reference to any metaphysical or spiritual source.

- It is the society that determines the uniqueness of human beings.

- One can be morally upright without necessarily being religious.

Unlike other ethics, such as Christian and Islamic ethics, Humanist ethics is based on happiness in this one and only life and not concerned with a supernatural realm, Immortality ${ }^{18}$ and the glory of God. Humanism denies the philosophical and psychological dualism of soul and body and contends that a human being is a oneness of mind, personality and physical organism. It can be deduced from the Humanist's concern for humankind, that international peace is a prime ethical objective. In working for peace, the Humanist combines self-interest with

\footnotetext{
${ }^{11}$ See American Humanist Association, Humanist manifestos i\&ii, http://www.americanhumanist.org- Retrieved 03/03/2016. See also Humanist manifestos i\& ii inLamont, C. (1997). Op. Cit..

12 See http://www.iheu.org/amsterdamdeclaration.

${ }^{13} \mathrm{Cf}$. http://www.nfuu.org/definitionsofhumanism.htm.

${ }^{14}$ Lamont, C. (1997). The philosophy of Humanism ( $8^{\text {th }}$ Ed.). Amherst, New York: Humanist Press, p. 13.

15 Cf. Lamont, C. (1997). The philosophy of Humanism (8 ${ }^{\text {th }}$ Ed.). Amherst, New York: Humanist Press, Chapter v.

16 Cf. American Humanist Association, Humanist manifesto ii, article four.

${ }^{17}$ See American Humanist Association, Humanist manifestos i \& ii ,http://www.americanhumanist.org - Retrieved 03/03/2014. See also Humanist manifestos $i$ \& ii in Lamont, C. (1997). Op. Cit..

${ }^{18}$ American Humanist Association, Humanist manifesto ii, article two.
} 
altruism making every possible effort for the successful functioning of the United Nations and for the permanent establishment of international peace (Lamont, 1980).Another ethical imperative for Humanism is the support of political democracy and liberties. Humanists rely primarily on reason and scientific method for the solution of all problems. They necessarily uphold freedom of expression in all fields of human endeavor. Humanist ethics rejects resorting to threats or violence as a method of settling disputes.

The ethics of Humanism incorporates whatever seems relevant from other philosophies or religions, even while rejecting their theologies. For Corliss Lamont, some of the Decalogue, can be understood as principles of Humanist ethics. They include "Thou shall not steal", "Thou shall not kill", "Honor thy father and thy mother", "Thou shall not bear false witness against thy neighbor" (Lamont, 1980). In fact, Humanist ethics acknowledges that there is much ethical wisdom in the New Testament ${ }^{19}$ and the teachings of Jesus. For example, the Humanist welcomes the words of Jesus when he says: "I have come so that they may have life and have it to the full" (John10:10).Another teaching of Jesus, namely, "The truth shall make you free,"(John 8: 32), is also in line with the ethics of Humanism. In fact, Humanist ethics claims that this quotation from Jesus can be made complete by adding that falsehood shall make you slaves (Lamont, 1980).

Paul Kurtz (1988) claims that there can be morality without religion. Kurtz sees morality as deeply rooted in the common moral decencies (these relate to moral behaviour in society) and the ethical excellences. For Kurtz, the common moral decencies are widely shared. They are essential to the survival of any human community. They are handed down through countless generations. They are recognised throughout the world by friends and relatives, colleagues and co-workers and the native-born or immigrants, as basic rules of social intercourse. They express the elementary virtues of courtesy, politeness, and empathy so essential for living together. Indeed, they are the very basis of civilised life itself. The common moral decencies are trans-cultural in their range and have their roots in generic human needs. The following are examples of the common moral decencies: ${ }^{20}$ (a) Personal integrity; ${ }^{21}$ (b) Trustworthiness; ${ }^{22}$ (c) Benevolence; ${ }^{23}$ (d) The principle of fairness; ${ }^{24}$ Tolerance is also a moral decency; one should also respect other individuals' rights to their beliefs, values, and styles of life, even though they may differ from one's own. Each individual is entitled to his convictions as long as one does not

${ }^{19}$ American Humanist Association, Humanist manifesto ii, http://www.americanhumanist.org - Retrieved 03/03/2014.

${ }^{20}$ Kurtz, P., (1988). Forbidden fruit: The ethics of Humanism, N.Y.: Prometheus Books, pp. 93-110.

21 Personal integrity involves moral values such as telling the truth, not lying or being deceitful; being sincere, candid, frank, and free of hypocrisy; keeping one's promises, honouring pledges, living up to agreements; and being honest, avoiding fraud. See Kurtz, P., (1988), Op. Cit..

22 Trustworthiness deals with loyalty to ones relatives, friends and co-workers, being dependable, reliable, and responsible. See Kurtz, P., (1988), Op. Cit..

${ }^{23}$ Benevolence involves manifesting goodwill and noble intention and having a positive concern for one`s fellow human beings; Avoidance of malicious acts that can harm to other persons or their property. One should not kill or rob; inflict physical violence or injury; or be cruel, abusive or vengeful. This implies the moral obligation to be beneficent, that is, kind, sympathetic, compassionate and lend a hand to those in distress and try to decrease their pain and suffering and contribute to their welfare. See Kurtz, P., (1988), Op. Cit..

24 The principle of fairness demands that one should show gratitude to those that deserve it; Being civil and holding people accountable for their deeds, insisting that those who wrong others do not go completely unpunished and perhaps must make reparations to the aggrieved. This also involves the principle of justice and equality in society. See Kurtz, P., (1988), Op. Cit.. 
harm others or prevent them from exercising their rights. Humans should try to cooperate with each other, seeking to negotiate differences peacefully without resorting to hatred or violence.

Humanism sees the common moral decencies as general principles and rules and individuals or nations may deviate from practicing them. In fact, the moral decencies are not absolute but general parameters to guide human conduct. Sometimes they may conflict and humans may have to establish priorities between them. They need not be divinely ordained to have moral force, for they are tested in the last analysis by their consequences in practice.

On sexuality, humanist ethics affirms that one should not force one`s sexual passions on others. Rather, a sexual relation should be a mutual consent between adults. Humanist ethics allows sexual freedom, homosexuality, abortion, birth control and easy divorce of marriages.

\section{The Ethical Excellences}

According to Humanist ethics, some of the ethical excellences ${ }^{25}$ are the following: Autonomy, ${ }^{26}$ intelligence ${ }^{27}$ and reason, self-discipline, ${ }^{28}$ self-respect, ${ }^{29}$ creativity, ${ }^{30}$ high motivation, ${ }^{31}$ affirmative attitude, ${ }^{32}$ joie de vivre, ${ }^{33}$ good health ${ }^{34}$ and exuberance. ${ }^{35}$

Lamont (1980) summarises Humanist ethics into eleven main points which he describes as guiding principles not absolutes. They include the following: (1) Humanist ethics is concerned wholly with actions, ideals and values on this earth in our and only life. The utopia that is heaven must be built in this world or not at all. (2) Humanist ethics is an affirmative one of joy and happiness, repudiating the Christian idea of original sin in human beings and any sense of puritanism. (3) Humanist ethics holds a liberal view on sex relations, but insists on high

\footnotetext{
${ }^{25}$ Cf. Kurtz, P., (1988). Forbidden fruit: The ethics of Humanism, N.Y.: Prometheus Books, pp. 133-143.

${ }^{26}$ Autonomy: A person's autonomy is an affirmation of one's freedom. See Kurtz, P., (1988), Op. Cit..

27 Intelligence and reason are high on the scale of values. According to this humanist ethical excellence, to achieve the good life, one needs to develop one's cognitive skills that can help the individual to make wise choices. See Kurtz, P., (1988), Op. Cit.

28 Self-discipline: One needs self-discipline over one's passions and desires. Self-discipline involves moderation under the guidance of rational choice, recognizing the harmful consequences that imprudent choices can have upon the individual and others. See Kurtz, P., (1988), Op. Cit..

${ }^{29}$ Self-respect is vital for a human being's psychological balance. Self-hatred can destroy one's personality. This implies that there is the need to develop some appreciation for oneself as an individual and a realistic sense of one's own identity. See Kurtz, P., (1988), Op. Cit..

${ }^{30}$ Creativity is closely related to autonomy and self-respect. It highlights the fact that the independent person has some confidence in his/her own powers and is willing to express his/her unique talents. The uncreative person is usually a conformist. See Kurtz, P., (1988), Op. Cit..

${ }^{31}$ High motivation involves willingness to enter into life and undertake new plans and projects. A motivated person finds life interesting and exciting. See Kurtz, P., (1988), Op. Cit..

32 Affirmative attitude deals with the need for one to cultivate some measure of optimism that what one does will matter. Although one may suffer defeats, one must believe that one will overcome and succeed despite adversities. 33 Joie de vivre: The individual human being must have full appreciation for the full range of human pleasure from the so-called bodily pleasures such as food and sex to the most ennobling and creative aesthetic, intellectual and moral pleasures. See Kurtz, P., (1988), Op. Cit..

${ }^{34}$ Good health: This implies that one avoids smoking and drugs, drinks only in moderation, seeks to reduce stress in one's life, and strives to get proper nutrition, adequate exercise, and sufficient rest, and to achieve sexual fulfillment and love. See Kurtz, P., (1988), Op. Cit..

35Exuberance is an active, not a passive, process of perfecting one's talents, needs, and wants. The end or goal of life is to live fully and creatively, sharing with others the many opportunities of life. Contrary to the biblical injunction in Genesis chapter three, Humanist ethics posits that this can be found by eating the succulent fruit of the tree of life and by living in the here and now as fully and creatively as one can. See Kurtz, P., (1988), Op. Cit..
} 
standards of conduct and believes in the institution of marriage, with easy divorce and some latitude of sexual variety for husband and wife. (4) Humanist ethics relies on reason and scientific method in working out ethical decisions. There is no room for prayer or divine guidance by some supernatural being. (5) While Humanism believes in general ethical principles, most ethical decisions must be considered on an individualistic basis that evaluates the probable consequences and possible alternatives. (6) In the age-long dialogue on selfinterest versus altruism, Humanist ethics sees a false dichotomy and claims that a man or woman can harmoniously combine relative self-interest and relative altruism in working for the community good. (7) The community good is one's family, one's state, one's nation, or all humanity; with the happiness and progress of the entire human race as the ultimate community good and the supreme ethical aim of Humanism. (8) It follows from ordinary selfinterest and the Humanist's concern for fellow humans that international peace is a principal ethical objective. This is truer today than ever before in view of the terrible nuclear weapons that have developed and which threaten, if used in a war, the existence of all humankind. (9) Humanism is eclectic and incorporates whatever seems relevant from other philosophies or religions. For instance, many of the Christian precepts in the New Testaments have an important place in the ethics of Humanism. (10) The support for democracy and civil liberties is an ethical imperative for Humanism, with complete freedom of expression in every field of human endeavour. (11) The Humanist ethics functions on the basis that human beings have true freedom of choice at the moment of making an ethical decision. Universal determinism that includes humankind would make any sort of ethics impossible and irrelevant.

\section{Similarities and dissimilarities}

Even though the Lifeboat ethics and Humanist ethics have common sources, namely, reason and science, a critical examination manifests that there are several dissimilarities in their moral values/principles that outnumber and outweigh the similarities.

\section{Similarities}

The following are some of the features that are common to both the lifeboat ethics and Humanist ethics.

1. Reason and science are the sources for both the lifeboat ethics and Humanist ethics.

2. The lifeboat ethics and Humanist ethics focus on issues that pertain to the human society here-and-now.

3. Both ethics do not make any reference to the life hereafter or the netherworld.

4. Humans feature prominently in both ethics. Whereas the lifeboat ethics discusses the gap or relationship between the rich and poor human beings in this world, Humanist ethics also focuses on humans in this present life, discussing variety of issues such as religion, ethics (treating issues such as abortion, suicide and euthanasia); the individual human being (including one`s sexual proclivities and desires); democratic society; the world community and humanity as a whole.

5. In another perspective, both the lifeboat ethics and the Humanist ethics do not involve the belief in and the role of a supernatural being in their respective ethical principles. This common characteristic of the lifeboat ethics and the Humanist ethics is different from other types of ethics, such as Christian ethics, ${ }^{36}$ Islamic ethics ${ }^{37}$ and Traditional

\footnotetext{
${ }^{36}$ See for example Ramsey, P. (1953). Basic Christian ethics. New York: Scribner`s Sons, p. 1; See also Kunhiyop, S. W. (2008). African Christian ethics. Nairobi, Kenya: Word Alive Publishers, pp. 51-54.

${ }^{37}$ Cf. Surah Al-Baqarah 2:177 which says "Righteousness is not that you turn your faces toward the east or the west, but (true) righteousness is (in) one who believes in Allah, the last day, the angels, the Book...";Surah Ali Imran 3:110, "You are the best nation produced (as an example) for mankind. You enjoin what is right and forbid what is wrong and believe in Allah;" See also Parrinder, G. (Editor), (1983). World religions from ancient
} 
Akan ethics ${ }^{38}$ that acknowledge the belief in and the role of a supernatural being in their respective ethics.

6. Furthermore, unlike Christian ethics, Islamic ethics and Traditional Akan ethics wherein there is a dimension that deals with how one`s good moral life in this present life can merit one a good reward in the life hereafter, both the lifeboat ethics and the Humanist ethics do not have such a dimension. In fact, both the lifeboat ethics and the Humanist ethics do not relate good/bad moral life in this present life to a good/bad reward in the metaphysical immortal life in their respective ethics.

\section{Dissimilarities}

Among the dissimilarities between the lifeboat ethics and Humanist ethics, the following can be identified.

1. The moral value that Humanist ethics accentuates in altruistic acts which benefit one's fellow human being seems to be a different case in the lifeboat ethics. In the lifeboat ethics, the aid that the rich in society extends to the poor, apparently benefits the poor but de facto, the said charitable act will ultimately benefit the rich since it prevents the poor outside the lifeboat from rebelling against the rich inside the lifeboat and consequently, there is an apparent peace that maintains and ensures that the gap between the rich and the poor is not disturbed. In this context, it could be deduced that in the lifeboat ethics, the rich utilizes altruistic act as a means to achieve an egoistic end.

2. In a further dissimilar vein, whereas the mastermind of the lifeboat ethics is a single individual, namely, Garrett Hardin, Humanist ethics is a result of several minds, including numerous signers of the Humanist manifestos, which as it were, serve as a compendium of the principles and stances of Humanist ethics.

3. Furthermore, whereas the lifeboat ethics is based on one theory, namely, the lifeboat theory, Humanist ethics is open to other philosophies and the boundless limits of reason and scientific methods thereby gaining the advantages of progressiveness, flexibility, tolerance openness to new developments and the like because Humanism is indeed eclectic.

4. The lifeboat ethics asserts that the rich are in the lifeboat while the poor are outside the boat. This form of economic stratification may be prevalent in some human communities. However, the total segregation of the rich from the poor, whereby the former and the latter live apart geographically and functionally, as propounded by the lifeboat ethics is not easy to find, if not completely unrealistic, in any human society. Realistically, a normal human society manifests an amalgamation of both the rich and the poor living together and depending on each other in a single society or community as asserted by Humanist ethics. In fact, refuting segregation, Humanist ethics affirms communal life characterized by inter-relatedness among humans as follows:

We deplore racial, religious, ethnic, or class antagonisms. Although we believe in cultural diversity and encourage racial and ethnic pride, we reject separations which

history to the present. New York, N.Y.: Facts on File Publications, that affirms that "Muslims (literally, those who make or do Islam), as followers of the movement are known, indicated by the very name that they have committed themselves into the hands of a sovereign divine ruler, whose will it is their purpose to follow in every aspect of life"(p. 462).

${ }^{38}$ See Danquah, J. B. (1944). The Akan doctrine of God: A fragment of Gold Coast ethics and religion. London: Lutterworth Press, p. 3; Ackah, C. A. (1988). Akan ethics. A study of the moral Ideas and the moral behaviour of the Akan tribes of Ghana. Accra: Ghana Universities Press, p. 7.See also Sarpong, P. K. (1972). "Aspects of Akan ethics," in Ghana Bulletin of Theology, Vol. 4,No. 3, pp. 40-54; Appiah-Sekyere, P. (2014). The Lifeboat Ethics and Traditional Akan Ethics: A Critical Comparative Study, in International Institute for Science, Technology and Education, Vol. 4, No. 2, pp. 28; See also Appiah-Sekyere, P. (2016). Traditional Akan Ethics and Humanist ethics: A Comparative Study, in Advances in Social Sciences, Research Journal, Vol. 3, No. 6, p. 110. 
promote alienation and set people and groups against each other; we envision an integrated community where people have a maximum opportunity for free and voluntary association. ${ }^{39}$

5. In another perspective, whereas the lifeboat ethics focuses on a single scope, precisely, the moral responsibility of the rich towards the poor, Humanist ethics is wider in scope dealing with various aspects of human life such as religion, ${ }^{40}$ ethics, ${ }^{41}$ marriage, ${ }^{42}$ sex, ${ }^{43}$ abortion, ${ }^{44}$ euthanasia, ${ }^{45}$ suicide, ${ }^{46}$ international peace, ${ }^{47}$ poverty ${ }^{48}$ and the environment. ${ }^{49}$

6. Albeit Humanist ethics rejects "traditional dogmatic or authoritarian religions that place revelation, God, ritual, or creed above human needs and experience" as doing a "disservice to the human species" nonetheless, it incorporates ${ }^{50}$ whatever seems relevant from other philosophies or religions. Thus Humanist ethics promotes openness and communalistic moral behavior among humans while the lifeboat ethics is individualistic, segregational and egoistic.

7. Whereas, primarily, the lifeboat ethics seeks the welfare and the maintenance of the status quo of the rich in the lifeboat, Humanist ethics seeks to promote a democratization of the world economy that can be judged by its responsiveness to human needs, testing results in terms of the common good. In fact, whereby some individuals are unable to contribute to their own betterment, humanist ethics endorses that society provides the means to satisfy the said individuals' basic economic, health, and cultural needs. ${ }^{51}$

8. Actually, Humanist ethics categorically affirms that Humanists "are concerned for the welfare of the aged, the infirm, the disadvantaged, and also for the outcasts - the mentally retarded, abandoned, or abused children, the handicapped, prisoners, and addicts - for all who are neglected or ignored by society. In this context it is crystal clear that the altruistic care as a moral value in Humanist ethics far outweighs that which the rich show to the poor in the lifeboat ethics.

\section{EVALUATION AND CONCLUSION}

Notwithstanding the fact that the Lifeboat ethics and Humanist ethics are both based on human reason and science, without reference to a supernatural being, thus showing similarity in

\footnotetext{
${ }^{39}$ American Humanist Association, Humanist manifesto ii, article eleven; See also Humanist manifestos ii, in Lamont, C. (1997). The Philosophy of Humanism (8 ${ }^{\text {th }}$ Ed.). Amherst, New York: Humanist Press, p. 323.

40 See American Humanist Association, Humanist manifesto ii, articles one and two. From http://www.americanhumanist.org- Retrieved 03/03/2014.

41 American Humanist Association, Humanist manifesto ii, article three and four.

${ }^{42}$ American Humanist Association, Humanist manifesto ii, article six; See also Humanist manifesto ii in Lamont, C. (1997). The Philosophy of Humanism (8th Ed.). Amherst, New York: Humanist Press, p. 321.

43 Ibid..

${ }^{44}$ Ibid..

${ }^{45}$ American Humanist Association, Humanist manifesto ii, article 7.

46Ibid..

${ }^{47}$ American Humanist Association, Humanist manifesto ii, article thirteen; See also Humanist manifestos ii, in Lamont, C. (1997). The Philosophy of Humanism (8 ${ }^{\text {th }}$ Ed.). Amherst, New York: Humanist Press, p. 324.

${ }^{48}$ American Humanist Association, Humanist manifesto ii, article ten; See also Humanist manifestos ii, in Lamont, C. (1997). The Philosophy of Humanism (8th Ed.). Amherst, New York: Humanist Press, p. 322.

${ }^{49}$ American Humanist Association, Humanist manifesto ii, article fourteen.

${ }^{50}$ For example, Corliss Lamont (1980) sees at least four of the Decalogue, namely, "'Thou shall not steal; Thou shall not kill; Honour thy father and thy mother; and Thou shall not bear false witness against thy neighbor," as moral principles of Humanist ethics.

51See American Humanist Association, Humanist manifesto ii, articles 10 and 11.
} 
sources, a further critical examination indicates that there are dissimilarities in their respective ethical values that outnumber and outweigh the similarities.

Furthermore, the lifeboat ethics with its efforts to maintain the status quo of the rich end up being myopic and narrow-minded in responding to human needs while Humanist ethics is more open, tolerant, and progressive dealing with several significant issues that contribute to sustainable development of humanity as a whole not just a selected group.

Whereas the lifeboat ethics is seemingly laudable and favourable to the rich, Humanist ethics endeavours to promote a humane world not only for the rich but also for the poor, who should not be treated as victims of segregation/discrimination because of their economic status but as fellow humans in one, and only one, human family.

From the above discussions, this paper asserts that two principles or issues may have a common source (like the lifeboat ethics and Humanist ethics) yet they can produce both similar and dissimilar results. In other words, the identical source is no guarantee of similar outcome. Neither can we be categorically sure that same input will always guarantee same output.

\section{References}

Ackah, C. A. (1988). Akan ethics. A study of the moral Ideas and the moral behaviour of the Akan tribes of Ghana. Accra: Ghana Universities Press.

American Humanist Association, Humanist manifestos i \& ii, http://www.americanhumanist.org-Retrieved 03/03/2014.

Appiah-Sekyere, P. (2011). Humanist ethics: Its relevance for Ghana today. Integrative Humanism Journal, Vol. 1, No. 1, pp. 3- 14.

Appiah-Sekyere, P. (2014). The Lifeboat Ethics and Traditional Akan Ethics: A Critical Comparative Study, in International Institute for Science,Technology and Education, Vol.4, No. 2, pp. 27-33.

Appiah-Sekyere, P. (2016). Traditional Akan Ethics and Humanist ethics: A Comparative Study, in Advances in Social Sciences, Research Journal, Vol. 3, No. 6, p. 110-120.

Boss, J. A., (1997). Perspectives on ethics. California: Mayfield Publishing Company.

Boss, J. A., (2006). Analyzing moral issues. London: Mayfield Publishing Company.

Danquah, J. B. (1944). The Akan doctrine of God: A fragment of Gold Coast ethics and religion, London: Lutterworth Press.

Gonsalves, M. A. (1989). Fagothey's right \& reason: Ethics in theory and practice. New Jersey: Prentice Hall.

Hardin, G. (1974). Lifeboat ethics: The case against helping the poor. Retrieved on 31st May, 2013 from http://www.garretthardinsociety.org/articles/art lifeboat ethics_case against helping_poor.html.

Kunhiyop, S. W. (2008). African Christian ethics. Nairobi, Kenya: WordAlive Publishers.

Kurtz, P., (1988). Forbidden fruit: The ethics of Humanism, N.Y.: Prometheus Books.

Lamont, C., (1980). "The Affirmative of Humanism” in The Humanist Magazine, Vol. 40,(2) March/April.

Lamont, C., (1997). The philosophy of Humanism, (8th ed.). Amherst, N.Y.: Humanist Press.

Parrinder, G. (Editor), (1983). World religions from ancient history to the present. New York, N.Y.: Facts on File Publications.

Ramsey, P. (1953). Basic Christian ethics. New York: Scribner`s Sons.

Sarpong, P. K. (1972). “Aspects of Akan ethics,” in Ghana Bulletin of Theology, Vol. 4,No. 3, pp. 40-54.

Shakir, M. H. (1988). The Qur`an. Elmhurst, N.Y.: TahrikeTarsile Qur`an Inc.

Singer, P. (1993). A companion to ethics, Mass.: Blackwell.

Sydney D., Ta'Von J. and Arman Ali, "Analysis of 'Lifeboat Ethics”" from 
Appiah-Sekyere, P. (2018). The Lifeboat Ethics And Humanist Ethics: Similarities And Dissimilarities. Advances in Social Sciences Research Journal, 5(5) 76-86.

http://hardinlifeboatethics.weebly.com/formal-essay-analysis-of-lifeboat-ethics.html. Retrieved 29/05/2016.

http://www.americanhumanist.org - Retrieved 03/03/2014.

www. Corliss-lamont.org/ethics.htm - Retrieved 4/3/2011.

http://www.iheu.org/amsterdamdeclaration - Retrieved 04/02/2015.

http://www.nfuu.org/definitionsofhumanism.htm - Retrieved 08/02/2014. 